\title{
SIR HENRY SOUTTAR
}

Sir Henry Souttar, C.B.E., died on November 12, 1964, at the age of 88 . A man of great versatility and charm, he was well known as a distinguished and daring surgeon.

Henry Sessions Souttar was born at Birkenhead on December 14, 1875. His father, Robinson Souttar, D.C.L., a native of Aberdeen, was a distinguished engineer in India and later M.P. for Dumfriesshire from 1895-1900. Souttar was educated at the Oxford High School and at Queen's College, Oxford, where he obtained a double first in mathematics. He was a keen athlete, notably an oarsman, and even when he was over 60 was fond of a row on the river. Before turning to medicine he took an interest in physics and engineering and acquired a basic knowledge that helped him later.

After joining the London Hospital in 1903 for his clinical work, he married, in 1904, Kitty the daughter of R. B. Clifton, F.R.S., Professor of Physics at Oxford. It was to prove a long and happy association for 55 years. They both loved Oxford and for a time had a home there as well as in London. His mathematical and engineering training made him older than most students when he qualified B.M., B.Ch., Oxon, in 1906. Subsequently he made rapid progress, becoming F.R.C.S. in 1909, surgical registrar in 1910, assistant surgeon to the West London in 1912, and to the London Hospital in 1915.

In 1914, he went to Antwerp as Surgeon-in-Chief to the Belgian Field Hospital and took part in the dangerous and weary evacuation to Furnes, near the front line when the battle raged round the Ypres Salient. He wrote a graphic account of his experience in A Surgeon in Belgium. Later, he was chief surgeon to the British Red Cross Hospital at Netley. After the war, he returned to the busy life of a surgeon at the London Hospital. In 1920, he was appointed director of the new surgical unit there, and the same year wrote his book on Injuries of the Peripheral Nerves. This was followed by The Art of Surgery six years later. Meanwhile, in 1925, he had performed his historic operation for mitral stenosis (see later). Apart from this one adventure, Souttar was a general surgeon with a broad range, and wrote widely especially about the surgery of the mouth and œsophagus. His knowledge of physics helped him to play a leading part in the development of radium therapy and the use of radon seeds. He became Consulting Surgeon to the Radium Beam Therapy Research and wrote two books, Radium and its Surgical Applications and Radium and Cancer. He was a kindly examiner for many universities and his College. Souttar had the necessary training and a genius for mechanics and had his own workshop; many of the surgical instruments he devised were used all over the world. These included the atraumatic intestinal needle, an œsophagoscope, special tubes for intubation, a craniotome, and an introducer for inserting radon seeds.

Souttar showed administrative ability and was always ready for work. Few can have been chairman of so many important bodies. His friendliness and his large impressive figure with his bull-dog face and his hearty laugh no doubt helped, but his colleagues must have trusted his good judgement and commonsense. He became Vice President of the Royal College of Surgeons in 1943; and his share in including the Faculties of Dental Surgeons and of Anæsthetists within the College is, perhaps, among his most important achievements. As early as 1922 he was member of the council of the B.M.A. In 1934-37 he was Chairman of the Representative Body and in 1939-43 Chairman of Council. This was followed by his appointment as President of the B.M.A. and he established a record by holding these three offices-the highest in the Association. As Chairman of the Central Medical War Committee, he undertook an official visit to India in 1942 and helped with the reorganization of the surgical work there. He was also for many years Chairman of the Invalid Children's Aid Association. 
Souttar will be remembered as the first man who used his finger to explore a valve and its orifice and the first in Britain to operate on the mitral valve (May 6, 1925). Re-reading his account (Brit. med.J., 1925, 2, 603) I was surprised at the modernity of his views. In spite of the current teaching, his mechanical training made him aware of the disability due to the mitral stenosis as such, however much this might be increased by changes in the muscle. He wrote "the relief of the lesions themselves would undoubtedly be of immense service to the patient", "the method of digital exploration through the auricular appendage cannot be surpassed for simplicity and directness", and "I felt an appreciation of the mechanical reality of stenosis and regurgitation which I never before possessed." He decided there was no need to increase the mitral opening which admitted his finger, and was content to break down the adhesions that tethered down the cusps. His patient, a girl aged 15, lived for seven years and was one of the only two who survived these early attempts. It is surprising that Souttar was not asked to operate on others: he had done all that was then possible, but there was no great improvement and the physicians concerned did not recognize this was because the patient had preponderant mitral regurgitation. A photograph of the heart at necropsy has been published by William Evans in his Schorstein Memorial Lecture (London Hospital Gazette, Supplement to Vol. 64, 1961).

Many years later, Sir Henry Souttar was made an Honorary Member of the British Cardiac Society. He attended their dinner as the Society's guest after the autumn meeting in 1957, and spoke shortly about his first operation for mitral stenosis 32 years before.

Among his many interests was music: he was a good pianist and late in life took to playing the violin. He was a great reader of history and found pleasure in reading Homer in the original. As churchwarden of St. Marylebone Parish Church for 42 years he took a constant interest in its affairs.

His wife died in 1959, and in 1963 he married Mrs. Amy Wigdahl, a widow and an old friend of the family. To her and to his son and daughter we offer our deep sympathy.

MAURICE CAMPBELL 